\title{
Positive Liberty and Black Female Subjectivity in Toni Morrison's Sula
}

\author{
Najd F. Alfaqir ${ }^{1}$ \\ ${ }^{1}$ Department of Literature, American University, Washington DC., United States of America \\ Correspondence: Najd F. Alfaqir, Department of Literature, American University, Washington DC., United States of \\ America.
}

Received: May 12, 2018

Accepted: May 25, $2018 \quad$ Available online: May 28, 2018

doi:10.11114/ijsss.v6i6.3316

URL: https://doi.org/10.11114/ijsss.v6i6.3316

\begin{abstract}
The essay investigates the representation of female subjectivity that is disturbed by issues of race, gender, and community in Toni Morrison's novel, Sula. In my analysis, I bring to bear both the works of postmodernist theory and contemporary Feminist aesthetics in order to strengthen female subjectivity against the closed systems in which black women are objectified and separated from the autonomous existence they deserve. My representation of postmodernism is inspired by Linda Hucheon's theory of Postmodernism in A Poetics of Postmodernism: History, Theory, Fiction. Her suggestion that postmodernism is a contradictory concept that simultaneously acknowledges and disregards any concept offers new possibilities; it blurs the lines that humans create between self/other and centered/decentered, undermining socially constructed notions of good and bad. As I closely examine the character of Sula, who embodies such postmodern concept, I attempt to rethink her position as marginalized and evil to think about her character as a quest to rise above the limitations resulting from the closed systems in which black women are objectified. In my conclusion, I suggest that Sula's presence in the novel as radical on the surface is positive, for she transforms her otherness into a space from which female autonomy and liberty emerge. Throughout Sula, Morrison explores spaces of existence beyond constructed social conventions towards female individuality and Sula epitomizes that in her positive liberty.
\end{abstract}

Keywords: postmodernism, society, individuality, female subjectivity, marginalized identities, race, positive liberty, womanhood

\section{Introduction}

Two of the many questions that Toni Morrison's Sula raises are why does Sula's story end way before the novel's ending, and why is it that Nel is the one who survives until the very last page of the book. In the article "New World Woman': Toni Morrison's Sula," Maggie Galehouse (1999) attempts to answer these questions. She negotiates the novel's two characters of Sula and Nel as representing, respectively, "the good side of bad and the bad side of good. Sula lives according to her own design and, for that independence, dies early and alone ... - but as she says, 'my lonely is mine' (p. 143). Nel survives but it is only on the final page of the novel that she begins to understand that it is Sula, and not Jude, who she has been missing for decades" (Galehouse, 1999, p. 359). Reading Nel as the "traditional hero" and Sula as the one who cannot be sustained without Nel, Galehouse argues, "ultimately, Sula shows that a novel cannot rely upon a character who, while compelling and experimental, does not really grow" (p. 360). Sula cannot "sustain a traditional role" as Nel does by "approach[ing] movement, change, and transcendence" (p. 361). According to Galehouse's reading, Sula cannot survive in the novel because she cannot move forward.

While Galehouse's (1999) contrast between Nel and Sula is logical, Morrison (2004), by situating Sula as the central character of the novel, offers more than a traditional role; her character opens more possibilities for living a liberated womanhood despite the constraints of gender, race, community, and history which are socially constructed and determined. The reason Sula does not survive within her community and until the end of the novel signifies her occupation of a status that her community has not yet reached. She cannot exist anymore because her radicalness is not yet acknowledged by her community. On the other hand, Nel's existence long after Sula's death shows the extent to which she, along with the community that she resembles, is still caught up in socially constructed notions of reality that limit the individual to his/her acceptable social role.

Notably, Sula's story does not end with her death, for her name appears on the final page of the novel, signifying the importance of her character. In an interview with Betty Parker (1994) in "Complexity: Toni Morrison's Women," Morrison talks about how Sula and Nel constitute two parts of one consciousness: "They complement each other. They 
support each other. I suppose the two of them together could have made a wonderful single human being" (P. 62). Sula's memory survives after her death in order to influence and enlighten Nel to find the truth behind her feeling of loss and her lack of female autonomy. In comparing the - in Morrison's words - "so-called good" Nel with the "so-called evil" Sula, the tone of the book and the stylistic approach that Morrison uses challenge the seemingly heroic notion of Nel that appears on the surface, which helps Sula sustain a full protagonist role that is positive in its radicalness. So, we must ask the question: how does the novel challenge our own conceptions of "good" and "bad"? Sula's radical aspiration for female subjectivity and her choice to live in accordance with her own will - while hard to label as good or bad - is positive, offering new possibilities for liberated existence free from the constructed and commonly accepted social and racial conventions which characterize her community.

The Bottom, where the events of the novel take place, is based on ironic contradictions and tensions that disable its women from fully achieving their womanhood. A piece of land given to a slave by his master in the city of Medallion, is located on a high hill but called the Bottom, which is the first ironic fact we learn about this place before we learn about its complicated inhabitants. On this land lives an African American community in which people occupy contradictory value systems that lead to constant tension on a collective and individual level. In this community, men leave their wives without being judged, while women are left with the burden of taking care of the household and children and receive judgments for their husbands' departure. As such, people's views of marriage and extramarital affairs are also contradictory. Setting the community this way, Morrison creates an ongoing tension among women themselves, problematizing concepts of love, friendship and womanhood, which become constantly conflicted and never resolved.

For example, the character Eva Peace embodies the contradictory individual values of the Bottom, and therefore never achieves a full sense of her womanhood. Eva suffers as an objectified woman. Her husband BoyBoy enjoys "womanizing" (Morrison, 2004, p. 32) her before he leaves her with the hardship of being a single mother whose love for her children drives her to kill one of them. As a result of her life, Eva - like her lost leg - loses her sense of womanhood, becoming a complicated character. Even though she suffers as a woman left alone without a man, she establishes masculine authority and holds biased views against women to favor men. Except for BoyBoy, Eva "love[s] all men;" in their presence, she enjoys "a good deal of teasing and pecking and laughter" (p. 41). To Eva, a single woman without a man seems very problematic; when Sula comes back in the second part of the novel, Eva antagonizes her for wanting to "make" herself instead of getting married and settling down, calling Sula "selfish" and telling her: "Ain’t no woman got no business floatin' around without men" (Morrison, 2004, p. 92).

Such a problematic individual as Eva exists within human-made social conventions that objectify the female characters in the novel and restrict them, not only to their gender role, but also according to their skin color. In the trip that Nel takes with her mother, Helene Wright, to New Orleans, she witnesses the way her mother is mistreated as a person of color-and as a woman. Living in the Bottom allows Helene to construct an upright and almost white identity, in which she lives according to social norms and the stereotyped roles of women. Even though this life allows her to escape her past as a daughter of a prostitute, this reality is demolished once she leaves the Bottom and travels to the south. In the train, Nel first witnesses how her mother gets humiliated by a white conductor, who castigates her for sitting in the Whites Only car. Helene smiles at the insult to escape the embarrassment, an act that - while making the black soldiers who witness the scene angry at her "dazzling" grin - positions her as fleshly desired, like her mother. Moreover, Nel realizes the implications of her mother's "custard-colored skin" (Morrison, 2004, p. 22) and its implications of her mother's status of being not as white as she aspires. Through this scene, Morrison illustrates the fragility of Helene's attempts to emancipate herself from her history or blackness.

Helene's inability to go beyond her mark as a black woman complicates her sense of womanhood. When we are introduced to Helene's life, the narrative tells us how, by living a "satisfactory" life, she wins "all social battles" of Medallion. Helene is an active woman in her community who goes to church and arranges social events. However, the narrative also shapes our views of Helene by showing the falsity of her satisfactory life. "She lost only one battle - the pronunciation of her name. The people in the Bottom refused to say Helene. They called her Helen Wright and left it at that" (Morrison, 2004, p. 18). This indicates that Helene's aspiration to create a satisfactory life by following social norms and aspiring to live according to her gender role does not strengthen her sense of individual significance.

Contrary to Eva, Helene, and other women in the novel, Hannah Peace, Sula's mother, does not abide by the social norms of the Bottom Community. Like her mother, Eva Peace, Hannah loved "maleness, for its own sake" (Morrison, 2004, p. 41), but she's different in that she is not objectified by the male gaze. She lives freely by her own choices without any obligations to conventional behaviors. Morrison describes her as a "sexually selfish" (Parker, 1994, p. 63) character, who "refuses to live without the attention of a man[.] ... [S]he [makes] men aware of her behind, her slim ankles, the dew-smooth skin and the incredible length of [her] neck. Then the smile-eyes, the turn of the head--all so welcoming, light and playful" (Morrison, 2004, p. 42). Hannah makes a man feel "as though he were complete and 
wonderful just as he was - he didn't need fixing" (Morrison, 2004, p. 43) in order to fulfill her sexual needs. Besides being in control of her own sexuality, she keeps men on her side: "The men, surprisingly, never gossip[] about her[;] ... they defend her and protect her from any vitriol that newcomers or their wives might spill" (Morrison, 2004, p. 44). Despite Hannah's radical character and the gossip about her, people "miss her when she is gone. And they take care of her when she burns and weep for her when she dies" (Parker, 1994, p. 63). Hannah surely lives her life more fully than Eva and Helene because her choice to follow her desires frees her from any compulsions to conform to her community's constructed notions of gender.

Under the shadows of Hannah's independence and Helene's conformity, Sula and Nel develop a beautiful friendship shaped by a pure sense of self, at first uninfluenced by their social surroundings. When Nel contemplates the trip South she took with her mother, she experiences an internal separation from her mother - or, in other words, a separation from the conventional world that shaped her mother's life: "She looked for a long time and suddenly a shiver ran through her. 'I'm me,' she whispered. 'Me.' Nel didn't know quite what she meant, but on the other hand she knew exactly what she meant. 'I'm me. I'm not their daughter. I'm not Nel. I'm me. Me.' Each time she said the word $m e$ there was a gathering in her like power, like joy, like fear" (Morrison, 2004, p. 28). This experience as a child allows Nel to live an authentic life, which her friendship with Sula strengthens. The novel describes the friends as complementing and completing one another: "So when they met ... they felt the ease and comfort of old friends. Because each had discovered years before that they were neither white nor male, and that all freedom and triumph was forbidden to them, they had set about creating something else to be. Their meeting was fortunate, for it let them use each other to grow on" (Morrison, 2004, p. 52). With each other, Sula and Nel find a kind of intimacy that distances them from the confinement of their community and gives them a pure and harmonious sense of individuality and freedom.

However, this intimate relationship between the two girls gets complicated when both come across certain circumstances during their adolescence, affecting the way they live their lives as adults. Nel's mother and her tendency to conform to socially acceptable roles strip away the sense of authenticity or "me-ness" (Morrison, 2004, p. 29) that Nel finds with Sula. As a result, Nel grows to live within the traditional familial configuration by which she is restricted from her "me-ness." As a child, "[u]nder Helene's hand[,] [Nel] became obedient and polite. Any enthusiasms that little Nel showed were calmed by the mother until she drove her daughter's imagination underground" (p. 18). When she grows up, Nel weds Jude Greene, but neither of them marry for love; their marriage is based more on need than desire. Jude "wasn't really aiming to get married" (p. 80) and Nel "seemed receptive but hardly anxious" (p. 82). Their marriage lacks feeling and passion, fulfilling Jude's sense of maleness instead of providing happiness and love. Nel's marriage to Jude demonstrates how women in the novel exist to satisfy men, subordinate themselves to them rather than complementing them. Jude "needed some of his appetites filled, some posture of adulthood recognized" (Morrison, 2004, p. 82). Marrying without passion and absorbing the female role that her mother constructs for her, Nel completely loses her sense of "me-ness" and, therefore, becomes unable to live with a liberating sense of individuality. Her mother's influence manipulates Nel, so that she cannot see a way out of the role society expects of her and she develops a stunted consciousness. Both Nel and Helene's characters are manifestations of the social values they subscribe to, thereby problematizing their autonomy.

While Helene's influence on Nel strips Nel's "me-ness" away from her, Hannah provides a model that sharpens Sula's individuality. Unlike other female characters in the novel, Sula and her mother are the only ones who manages to live solely according to their desires; yet, Sula goes beyond her mother by overcoming the predetermined identities of the Bottom. This happens due to two main incidents that change her life. First, Sula overhears her mother's conversation with her friends about mothering. When Sula hears her mother say that she loves her but does not like her, she learns that emotions are ambivalent and unreliable. More specifically, Hannah's words shape Sula's view of maternal love. Second, when Sula lets go of Chicken Little's hands, leading to his death by drowning, the experience teaches Sula humans' tenuous control over situations. Morrison (2004) writes of Sula:

$[\mathrm{H}]$ ers was an experimental life - ever since her mother's remarks sent her flying up those stairs, ever since her one major feeling of responsibility had been exorcised on the bank of a river with a closed place in the middle. The first experience taught her there was no other that you could count on; the second that there was no self to count on either. She had no center, no speck around which to grow ... She was completely free of ambition, with no affection for money, property or things, no greed, no desire to command attention or compliments - no ego. (p. 119)

These external influences complicate Sula's character; she trusts neither others nor herself. As a result, Sula lives an experimental life that allows her the opportunity for living authentically, without "compulsion to verify herself - [to] be consistent with herself" (Morrison, 2004, p. 119) and, therefore, to others.

Sula's character and her behaviors embody the postmodern concept of a contradictory phenomenon as described by 
Linda Hutcheon (1947) in her book, A Poetics of Postmodernism: "one that uses and abuses, installs and then subverts, the very concept it challenges" (p. 3). This contradiction is initiated as an act of decentralizing/ denaturalizing the conventional and cultural discourse within which we live. For example, in terms of "value, meaning, control, and identity," postmodernism acknowledges such terms and also "deliberately undermines them" (Hutcheon, 1947, p. 13). Sula embodies this idea through her behaviors as well as the way she views things. For example, Sula adopts her mother's incapability of "jealousy" and rejects affairs that contain "no passion" (Morrison, 2004, p. 44). Moreover, instead of inheriting her mother and grandmother's man-love, Sula grows a love for her own, pure, naked self. At the same time, Sula acknowledges the fact that she cannot fully survive the objectification that other women in her community suffer. One day on a summer afternoon, twelve-year-old Sula - who shares excited imaginations about the other sex with $\mathrm{Nel}$ - walks with her friend to the ice-cream parlor, with a "valley of [male] eyes" gazing at them. Ajax, who was among those eyes, says "Pig meat" (Morrison, 2004, p. 50), referring to the two girls. At the time, the words instilled a feeling of delight in her, but the catcall's implications change as she grows older as she recalls this episode of her life. As an adult, Sula acknowledges this incident as an objectifying act when she meets Ajax again. The only thing that Sula remembers about Ajax was "the word he had called out to her years ago and the feeling he had excited in her then" (Morrison, 2004, p. 127).

Despite the crude comments Ajax made in the past, Sula falls in love and experiences an affection for him "so new and alien" (Morrison, 2004, p. 131) to her that she finally succumbs to the traditional role of women. She starts behaving like other housewives, cleaning the house and preparing meals as she waits at home for her male lover, which undercuts her view of herself as autonomous. Sula's fall into her community's traditional gender roles that she refuses to conform to illustrates the postmodern concept of push and pull between submitting to and subverting the concept that Sula very much challenges.

Hutcheon (1947) indicates the premise of postmodernism enacts a process of rethinking some of the standards of modernism. "Postmodernism questions centralized, totalized, hierarchized, closed systems: questions, but does not destroy. It acknowledges the human urge to make order, while pointing out that the orders we create are just that: human constructs, not natural or given entities ... [P]art of its questioning involves an energizing rethinking of margins and edges, of what does not fit in the humanly constructed notion of center" (p. 41). Such problematic or contradictory attributes of postmodernism are not meant to be resolved, but to be held in tension, which speaks to Sula's continuous tension with her family, friends, and community that never get resolved.

Sula's authenticity and living according to her own conventions are complicated because they contradict the conventional social view of the female which Nel becomes. Therefore, she becomes evil in the eyes of her community and is pushed further to the margins. After being absent for ten years, Sula comes back, radical and shameless, having affairs, betraying her friend, Nel, sending her grandmother to a care house, and receiving harsh judgments without caring. Sula "was [a] pariah, then, and knew it. Knew that they despised her and believed that they framed their hatred as disgust for the easy way she lay with men" (Morrison, 2004, p. 122). Therefore, because Sula does not appeal to Nel's truth as well as that of society at large, she becomes estranged and evil to her community. This way of representation reflects how the novel appeals to the assumption that humans have the "urge to make order" which appears in kind of rejection that it manifests towards what goes against it; if such orders are rejected by an individual, this individual is pushed from the center to the margins, and considered othered and deviant (Hutcheon, 1947, p. 41).

The fact that Sula's character embodies the contradictions of postmodernism, her presence in the novel as opposed to her community is not for one to destroy the other. Rather, the tension Morrison (2004) creates through Sula in the novel questions the exclusivity of the Bottom and the community's conceptions of good and bad. Through Sula's complexity and contradictions, the novel questions the "binaries that conceal hierarchies (self/other)" (Hutcheon, 1947, p. 61), going beyond the binary opposition of within and without the center. This position pushes further the modernist ambivalence towards the individual into an insight that opens up more possibilities. Hutcheon (1947) suggests:

There have been liberating effects of moving from the language of alienation (otherness) to that of decentering (difference), because the center used to function as the pivot between binary opposites which always privileged one half: white/black, male/female, self/other, intellect/body, west/east, objectivity/ subjectivity ... But if the center is seen as a construct, a fiction, not a fixed and unchangeable reality, ... the new and-also of multiplicity and difference opens up new possibilities. (p. 62)

Two conclusions emerge: one blurs the lines that humans create between the centered and the decentered (the normal and the supposedly abnormal because he/she breaks from the norm) and the other undermines socially constructed notions of good and bad. 


\section{Method}

\subsection{Challenging Evil}

To begin, through Sula's eyes, Morrison (2004) shows us how the marginalized is not evil, something that the community in the novel is unable to comprehend. The subject of gossips about Sula in the second part of the novel includes her association with Shadrack, an African-American soldier who comes back from war, after suffering a traumatic experience followed by shell-shock, to live a radical life. At the time Sula becomes a pariah in the Bottom, a girl named Dessie tells her friend about witnessing Shadrack "tip his hat" (Morrison, 2004, p. 116) at Sula. Shocked by Shadrack's behavior towards Sula, the girls decide to label both Shadrack - who has never been "civil to nobody!" and Sula as "two devils" (p. 117). However, looking back at Sula's meeting with Shadrack, early in the novel, challenges the image of him as radical and violent. When Sula is thirteen years old, she comes into Shadrack's house after the incident with Chicken Little, gathers her courage, and looks at him, seeing something different from the common knowledge about him. The othered and alienated Shadrack who "walked about with his penis out, who peed in front of ladies and girl-children, the only black who could curse white people and get away with it, who drank in the road from the mouth of the bottle, who shouted and shook in the streets" (p. 62), she now views differently. Seeing how harmless he is, Sula thinks, "no one with hands like that, no one with fingers that curved around wood so tenderly could kill her" (Morrison, 2004, p. 62). In this moment, Sula registers Shadrack's true nature as opposed to the image that was cultivated about him by the biases of the Bottom community. Consequently, the reader is no longer convinced about these two girls' conclusions about Sula and Shadrack's evilness. As a result, the falsity and negativity of the community's views are exposed, changing our view of the abnormal that becomes normal.

The novel's act of breaking social constructions through such exposures offers an alternative way of thinking that undermines notions of good and bad, and Sula becomes crucial to this new understanding. In their last conversation, Sula and Nel reflect upon their lives and the choices they have made. The conversation ends with Sula asking Nel, "how you know ... About who was good. How you know it was you? ... I mean maybe it wasn't you. Maybe it was me" (Morrison, 2004, p. 146). Through this question, Morrison invites us to rethink Sula's character and her behavior. While Nel represents a character who conforms to social norms and ends up misjudging the only person she ever understood, loved the most, and with whom she felt most human, Sula lives true to herself without any judgment towards others. Sula "had lied only once in her life--to Nel about the reason for putting Eva out, and she could lie to her only because she cared about her. When she had come back home, social conversation was impossible for her because she could not lie" (Morrison, 2004, p. 121). This positive nature of Sula which does not allow her to lie to others forces her readers to consider her question and rethink her character. Throughout the novel, Morrison wants us to understand that if we are to stand on Nel's side and decide to judge Sula, then the novel has not yet accomplished its purpose. Sula is not about judging what's good or bad; rather, it is about questioning the constructed notions of identity to which people conform. And Sula's presence and her radical nature is Morrison's tool for finding answers.

\subsection{Achieving New Possibilities}

Sula's radical behaviors in the novel manifest as spaces in which the stereotypical notions of male and female roles, which constrain women - and, sometimes, men - can be overcome. Sexual intercourse outside of marriage - an act that Nel repudiates - is one of the ways in which Sula undermines the stereotypical notions of male and female and feels most intimate with herself. She transcends preset social identities, enabling an emerging power that allows her a sense of female individuality. In the section "1939" Morrison (2004) introduces us to Sula's interiority through which we learn what sex means to Sula and what kind of experience it gives her:

During the lovemaking she found and needed to find the cutting edge. When she left off cooperating with her body and began to assert herself in the act, particles of strength gathered in her like steel shavings drawn to a spacious magnetic center, forming a tight cluster that nothing, it seemed, could break. And there was utmost irony and outrage in lying under someone, in a position of surrender, feeling her own abiding strength and limitless power. But the cluster did break, fall apart, and in her panic to hold it together she leaped from the edge into soundlessness and went down howling, howling in a stinging awareness of the endings of things: an eye of sorrow in the midst of all that hurricane rage of joy. (p. 122 - 23)

This passage is filled with contradictory images that mark, first, Sula's desire to obtain her individuality and sense of "me-ness" in the face of male sexual power and, second, how she accomplishes this through direct contact or confrontation. When Sula "assert[s] herself in the act," she feels a "tight cluster" of strength, which reveals her sense of rage and resistance to be "in a position of surrender" under the male's bodily power. But once this cluster "break[s]," Sula, in a moment of panic, realizes that achieving autonomy is not about resisting male power, for the act of resistance would means that she acknowledges her inferiority to her male counterpart. This happens when she "leap[s] from the edge into soundlessness," causing a new sense of being different from the man. As a result, her rage transforms into 
"transcendence" as Sula howls with "joy." This celebratory moment disrupts "the binary oppositions" (Hutcheon, 1947, p. 20) between conventional male and female roles, which becomes a space of "soundlessness" within which harmony as a result of difference - is achieved. Sula feels this within herself in the "postcoital privateness in which she met herself, welcomed herself, and joined herself in matchless harmony" (Morrison, 2004, p. 123). This scene allows us to see the "possibility" for breaking down the stereotypes of men and women that control the Bottom. This experience enables Sula to transcend conventional views of gender, finding by that her own female individuality as a different from man and, thus, parallel and equal to him.

Overcoming binaries and offering an alternative to socially constructed gender roles allows Sula to achieve her autonomy. More significantly, by undermining the center and showing its artificiality, Sula's character reflects Morrison's (2004) exploration of how to rise above the limitations of social conventions. This idea of rising above social limitations is reflected in Sabina Lovibond's (1990) article, "Feminism and Postmodernism," in which she advocates for a more powerful female subjectivity in the realm of postmodernism. Peter Zima (2015) describes Lovibond's feminist approach as "inspired by the late modern (not postmodern) hope that individual subjectivity will be strengthened and restructured by contemporary social movements" (p. 182). According to Lovibond (1990):

The long march towards autonomy by way of the conquest of our own stupidity (or more accurately, by making ourselves less susceptible to external determination) can be summed up in the word 'transcendence'. In the moral and political context, as in the epistemological one, to 'transcend' is to go beyond. The pursuit of a fully integrated subjectivity takes the form of an attempt to rise above our present mental limitations. (p. 159)

Lovibond's concept of transcendence and "fully integrated subjectivity" pushes further the postmodern concept of the subject in order to offer feminists the opportunity to break from the social norms that privilege male over female. Lovibond's approach "bears witness to the ideological refusal of feminist, ethnic, regional, and religious movements to be intimidated by postmodern critics of subjectivity and to be relegated to the archaic enclaves of contemporary society" (Zima, 2015, p. 183). Lovibond concludes her article by suggesting that the postmodern "idea of subjectivity as socially (or discursively) constructed, and thus as inherently fluid and provisional, opens up a world of possibilities," which allows women to "remake [themselves] as better-more autonomous, less pathetic - people: 'better' by [their] own present lights, of course, but that is simply a condition of engagement in cognitive activity" (p. 178). In a similar way, Sula's decentering and her living authentic to herself allows her to achieve these possibilities.

\subsection{Attaining Liberty}

Similar to Lovibond's advocacy for female subjectivity, Mae Henderson (2000) envisions black female writing as an act of privilege: "If black women speak from a multiple and complex social, historical, and cultural positionality which, in effect, constitutes black female subjectivity, ... the black woman writer not only speaks familiarly in the discourse of the other(s), but as Other she is in contestorial dialogue with the hegemonic dominant and subdominant or 'ambiguously (non)hegemonic' discourses" (p. 350 - 51). Therefore, according to Henderson, what distinguishes black women's writing is, "the privileging (rather than repressing) of 'the other in ourselves"' as black women writers enter a dialogue with "black men as blacks, with white women as women, and with black women as black women" (p. 351). Sula's howl, according to Henderson, is "a form of speaking in tongues and a linguistic disruption that serves as the precondition for Sula's entry into language" (Henderson, 2000, p. 360).

Therefore, through sexual intercourse, Sula's liberation from the male and female opposition and its tension becomes "an act of self-reconstitution as well as an act of subversion or resistance" to the hegemonic community within which she exists (Henderson, 2000, p. 360). She separates herself from associations with male figures such as Ajax and Jude. In that sense, Sula's decentering herself as "othered" and her transcendence form a character "in which soundlessness can be transformed into utterance, unity into diversity, formlessness into form, chaos into art, silence into tongues" (Henderson, 2000, p. 362) becomes positive. Her constitution of her individuality against the normalized and standardized social roles assures a possibility for female subjectivity that is otherwise almost impossible in this novel.

One way Sula achieves positive liberty is accomplished through her own unique way of viewing herself as equal to men, going beyond the restraints of gender and racial identities. Her autonomy allows Sula to no longer see herself as a woman or colored, but as an individual being, self-possessed until the last day of her life. In her last conversation with Nel, Sula replies to her friend's accusations and judgments by pointing out the need for breaking from male/female and black/white social categorizations, favoring her sense of "me-ness," the essence of female subjectivity. Nel tells Sula, "you can't have it all, Sula ... you can't do it all. You a woman and a colored woman at that. You can't act like a man. You can't be walking around all independent-like, talking what you want, leaving what you don't" (Morrison, 2004, p. 142). Sula confronts Nel's limited view, replying: "You say I'm a woman and colored. Ain't that the same as being a man?" (Morrison, 2004, p. 142). Sula ignores the distinctions Nel made about gender; she refuses to see the difference between a man and a woman. Nel's limitations and the fact that, in Morrison's own words, she "[carries] the weight of 
the world" (Parker, 1994, p. 62) as a result of her position in her community meets with Sula's freedom that allows her to fully believe that she "sure did live in this world" according to her own freedom and will (Morrison, 2004, p. 143).

Moreover, Sula's nonconformity not only offers her a true way of living in which she lives transparent with her own self, but also infuses Nel with new and positive ways of thinking that only exist as a result of Sula. Even though Nel seems unable to realize the truth behind Sula and the significance of her autonomy, Sula's radicalism opens up new ways of thinking for Nel that allows her to go beyond passivity. During Nel's interior monologue right after she discovers the affair between Sula and Jude, she remembers something Sula told her in the past: "The real hell of Hell is that it is forever" (Morrison, 2004, p. 107), which, at the time, Nel failed to understand. Sula's behavior, however, enables Nel to find new insights. She eventually realizes that

Sula was wrong. Hell ain't things lasting forever. Hell is change.[] Not only did men leave and children grow up and die, but even the misery didn't last. One day she wouldn't even have that. This very grief that had twisted her into a curve on the floor and flayed her would be gone. She would lose that too. (Morrison, 2004, p. 108)

Sula is so powerful that she evokes change, which is positive because her actions liberate Nel from the negative emotions Sula's betrayal created. Earlier in the novel, Nel admits that Sula "helped others define themselves" (p. 95), which is how Sula comes to affect Nel, who wonders, "why, even in hate here I am thinking of what Sula said" (p. 108). After a period of reflection, Nel experiences "nothing, just a flake of something dry and nasty in her throat," which later becomes externalized as a "gray ball" hovering by her side (p. 109). Thinking about Sula's words allows Nel to deal with her emotions, deciding to control them by denial. That fur-ball is "the only way she could get her mind off the flake in her throat" (Morrison, 2004, p. 109). Even though Sula does not help Nel completely fix her negative emotions, thinking of Sula helps Nel gain positive and, to an extent, empowering control over her emotional state.

\subsection{Rethinking Standard Judgements}

Sula's liberated spirit is also positive for it provides the reader new ways of thinking, forcing us to suspend our judgments. The narrative voice - through Sula - allows us to reconsider the constructed community within which a person is judged based on what is thought of as right or wrong. On Sula's narrative style, Philip Page (1995), in his book Dangerous Freedom, writes "the narrator manipulates readers, forcing the story onto them ... making them question their responses to such characters as ... Sula" (p. 64) herself. Through the direct interaction between Sula and her community in section "1939," the narrative voice shows us the extent to which Sula's individuality makes her appear as a victim regardless of how wrong she appears to be in the eyes of her community, which, when compared with Sula, is harsh in its judgments and conclusions. For example, when Sula returns after ten years of absence and when people start antagonizing her, the omniscient narrator exposes the Bottom's judgmental negativity. The narrator describes the Bottom as "spiders whose only thought was the next rung of the web" and "the wayward stranger who trips into their net" (Morrison, 2004, p. 120). Such a grotesque image that Morrison uses to describe the community that marginalizes Sula alerts us, as readers, not to look at Sula the same way her community does. The narrative tone in this section of the novel, therefore, exposes the community's biases against Sula's "experimental life" that is marked as evil because it does not meet their standards - not because Sula is truly evil.

The narrator also hints at some realities behind Sula's character that are far from evil. Sula does not care about what others think of her, which comes at the cost of feeling lonely. In the midst of people's gossip, she realizes that "no one would ever be that version of herself which she sought to reach out to and touch with an ungloved hand," which becomes alive through her "idle imagination" only (Morrison, 2004, p. 121). Moreover, the narrator tells how "there was only her own mood and whim" which she "decided to turn the naked hand toward it, discover it and let others become as intimate with their own selves as she was" (p. 121). These words reveal that Sula is not evil, for when she realizes that Nel joined the rest of the Bottom's conclusions about Sula's evilness, the narrator tells us that "it had surprised her a little and saddened her a good deal when Nel behaved the way the others would have" (p. 120). Sula does not act with deliberate malice, for she "had no thought at all of causing Nel pain when she bedded down with Jude" (p. 119). Rather, her complex personality allows her to transcend in ways that others in her community - including Nel - cannot, which causes problematic views about her. This passage also shows her desires to help people "become as intimate with their own selves as she was" (Morrison, 2004, p. 121), an attempt that her community's judgments will not allow to become a reality.

Able to transcend her limited community, Sula becomes magical, as Nel feels what the narrator describes as "magic ... loveliness that pressed in from the windows" (Morrison, 2004, p. 94), foreshadowing Sula's return in the second part of the novel. This magic attributed to Sula, which mirrors her status as marginalized, disappears once she becomes in a position similar to Nel: left alone by her lover's departure. After her passionate relationship with Ajax, he leaves her because he refuses to commit to Sula's passion. Reflecting upon the fact that she has misunderstood his actual name, 
Albert Jacks, Sula feels devastated. In a long sentence that takes the length of a paragraph, Sula remembers how she called him Ajax all these years before the narrative exposes her internal cries in italicized words. She remembers that time when she was a kid, leered at by Ajax and other men who used to "call[] [and] sing[] out to her and Nel and grown women too with lyrics like pig meat and brown sugar and jailbait and $O$ Lord, what have I done to deserve the wrath, and Take me, Jesus, I have seen the promised land, and Do, Lord, remember me" (p. 135 italics in original). With Ajax's departure, Sula is left to reflect upon her life and wonder why is it hard to live free from such labels and social constructs. This moment of exposure to Sula's interior agony moves her from the margins, forcing the reader to be sympathetic towards her.

\section{Results}

As a character, Sula raises more questions than answers. However, her existence offers new possibilities for living free from the conventions and constructed norms unnecessarily shape people's lives. Morrison's representation of Sula manifests as a radical but positive force that, while allowing Sula female subjectivity, ultimately brings Nel to a moment of awakening that occurs when she is fifty years old. Moreover, such representation allows a space for abolishing the constructed notions of living by which people are limited to their roles and racial identities. Sula's last words before she dies are:

Oh, they'll love me all right. It will take time, but they'll love me ... After all the old women have lain with the teen-agers; when all the young girls have slept with their old drunken uncles; after all the black men fuck all the white ones; when all the white women kiss all the black ... then there'll be a little love left over for me. And I know just what it will feel like. (Morrison, 2004, p. 145)

This passage indicates Morrison's ambition for a raised awareness of Sula's female individuality and the possibilities the novel offers through her. Sula's words seem to contradict the fact that she dies lonely, but what distinguishes her is that she owns her loneliness; as she tells Nel, "but my lonely is mine" (Morrison, 2004, p. 143). Besides forcing the reader to rethink Sula's moments of sorrow and her uniqueness in owning herself, Morrison, in this passage, illustrates the hope that, one day, Nel and others whom she resembles would understand the beauty of owning one's own loneliness.

\section{Discussion}

Even though it took Nel years, she eventually realizes that Sula was right in her autonomous living and the individuality which she never lived to celebrate with another. At the end of the novel, when Nel visits the cemetery for Eva Peace's funeral, as she passes by Shadrack, she suddenly realizes that it was Sula whom she was missing or, in other words, the part of her that she used to share with Sula but never sustained, her "me-ness." Nel's remembrance of her past with Sula, when, as she recalls, they "was girls together" (Morrison, 2004, p. 174), is an epiphany in which she realizes that she could have lived free from all that restricts her from being intimate with herself. Thinking about "all that time" (p. 174), Nel realizes that her life was spent in misery rather than contentment. Her final cry, "girl, girl, girlgirlgirl" (p. 174), brings her back to that sense of individuality and transparency with the self that she used to have before she conformed to social norms and values. In comparing this cry with Sula's howl - with which she transcends the binaries of her community Page (1995) argues that "Nel dissolves her fur-ball, a sign of her self-acceptance and internal harmony" (p. 76). Thus, this moment is a celebrated one, because it assures that Sula's positive effect is finally achieved as it becomes felt by Nel who regains her lost sense of "me-ness" at the end of the novel. Sula's autonomy is no longer felt in her imagination only nor has it pushed her to the margins.

This final scene of Sula signals Nel's elevated awareness beyond the limitations of socially constructed norms with the help of Sula. As Morrison (2004) introduces us to conflicted identities, relationships, and values, Sula becomes the most significant character, because her complexity challenges the fixed notions of good and bad, what is centered and what is marginalized. Through Sula and the tension between her and Nel, Morrison offers ways for liberating transcendence and shows alternative views of one's own self. Despite not being a traditional hero fully present in the novel and not reaping the benefits of her influences, Sula is a hero who defines the concept of positive liberty. Her effects on other characters in the novel is positive and it helps readers, together with Nel, to realize the need to move away from either/or standards as well as fixed conventional values.

\section{Conclusion}

Morrison (2004) begins Sula introducing us to the history of the Bottom before 1803, long before Sula's story begins and ends the novel twenty-five years after Sula's death. And the body of the novel brings readers to the fragments of a past in which Sula and Nel's stories take place in different years of their childhood, adolescence, and adulthood. Structured in this manner, the novel in itself becomes an act of reflection on the two major characters. Therefore, Morrison invites us, as readers, to rethink and reexamine these characters, their actions, and their position in their community. Ending the novel 
with Nel's epiphany towards the meaning of being intimate with herself, Morrison confirms Sula's significance in the text as a positive force, even in her moments of absence. Sula's character challenges and exposes the Bottom as a socially constructed community that diminishes its women's intimacy with their autonomous selves. Sula is more than just an embodiment of the postmodern phenomenon of contradictoriness (Hutcheon, 1947, p. 3). It is a novel through which Morrison captures the need to celebrate difference and suspend judgment by rejecting the gender and racial norms that objectify black females and separate them from the autonomous existence they deserve. In this retrospective novel, Morrison investigates spaces of existing beyond such constructed social conventions towards female individuality and Sula epitomizes that in her positive liberty.

\section{Acknowledgements}

I would like to thank professor Roberta Rubenstein, for sharing her wisdom with me and giving me instruction over the course of this research. I am also grateful for my colleague and friend, Jay Hardy, for sharing his thoughts on the earlier version of the manuscript and for proof-reading the final version of the essay.

\section{References}

Galehouse, M. (1999). 'New world woman': Toni Morrison's sula. Papers on Language \& Literature: A Quarterly Journal for Scholars and Critics of Language and Literature, 35(4), 339.

Henderson, M. G. (2000). Speaking in Tongues: Dialogics, Dialectics, and the Black Woman Writer's Literary Tradition. African American Literary Theory: A Reader, edited by Winston Napier. New York: New York University Press.

Hutcheon, L. (1947). A poetics of postmodernism: History, theory, fiction. New York: Routledge.

Lovibond, S. (1990). Feminism and Postmodernism. Postmodernism and Society, edited by Roy Boyne, and Ali Rattansi. Macmillan Education UK. https://doi.org/10.1007/978-1-349-20843-2_6

Morrison, T. (2004). Sula (1st Vintage International ed.). New York: Vintage International.

Page, P. (1995). Dangerous freedom: fusion and fragmentation in Toni Morrison's novels. University Press of Mississippi, Jackson.

Parker, B. J. (1994). Complexity: Toni Morrison's Women. Conversations with Toni Morrison, edited by Danille Taylor-Guthrie, Univ. Press of Mississippi.

Zima, P. V. (2015). Subjectivity and Identity: Between modernity and postmodernity. Bloomsbury Academic, New York; London.

\section{Copyrights}

Copyright for this article is retained by the author(s), with first publication rights granted to the journal.

This is an open-access article distributed under the terms and conditions of the Creative Commons Attribution license which permits unrestricted use, distribution, and reproduction in any medium, provided the original work is properly cited. 